\title{
Description of the larva of Xestia atrata (Morrison, 1874) (Lepidoptera: Noctuidae) with notes on the biology of the species
}

\author{
Matti Ahola, Kimmo Silvonen, Heikki Kronholm, Karl-Erik Lundsten \\ \& Pekka Robert Sundell
}

Ahola, M., Silvonen, K. Kronholm, H., Lundsten K.-E. \& Sundell, P. R. 2006: Description of the larva of Xestia atrata (Morrison, 1874) (Lepidoptera: Noctuidae) with notes on the biology of the species. — Entomol. Fennica 17: 6572 .

The description of the larva is based on an ex ovo rearing. Females laid eggs mainly on Dryas octopetala. Larvae were, however, fed on several plants, not only those of Rosaceae. Photographs of the larva as well as drawings of the mouthparts and chaetotaxy are shown. Egg and pupa are briefly described. According to the larval characters, the species shows resemblance to the $X$. specios $a$ group. Habitat and rearing experience are described in comparison with some other Xestia species occurring in the area.

Matti Ahola, Metsänreunantie 27 G, FI-85900 Reisjärvi, Finland; E-mail: matti @)mahola.pp.fi

Kimmo Silvonen, Pronssitie 28, FI-02750 Espoo, Finland; E-mail: kimmo. silvonen@hut.fi

Heikki Kronholm, Kyntäjäntie 13, FI-45120 Kouvola, Finland; E-mail: heikki. kronholm@pp.inet.fi

Karl-Erik Lundsten, Rintamamiehentie 7, FI-12650 Espoo, Finland; E-mail: kelundst@saunalahti.fi

Pekka Robert Sundell, Faunatica Oy, Lansantie 3 D, FI-02610 Espoo, Finland; E-mail: pekka.sundell@faunatica.fi

Received 2 December 2002, accepted 18 April 2003

\section{Introduction}

Xestia atrata (Morrison, 1874) occurs in coniferous forests of the boreal forest zone across Canada (Lafontaine et al. 1987) and the Palaearctic as far west as Härjedalen in Sweden (Ryrholm 1995), Kuusamo in Finland (Sundell \& Lundsten 2000) and South Ural in Russia (Nupponen \& Fibiger 2002). Populations of $X$. atrata are arranged in five subspecies. Two of them, ssp. atrata (Morrison, 1874) and ssp. yukona (McDunnough, 1921) are Nearctic. Two others are eastern Palaearctic, namely ssp. filipjevi (Sheljuzhko, 1926) and ssp. sikhotealinensis Kononenko, 1990 (Lafontaine et al. 1987, Fibiger 1997), and the fifth one, ssp. haraldi Fibiger, 1997 (Fibiger 1997), to which the specimens from Kuusamo belong, was described from Sweden. The early stages of the species have so far been unknown. 


\section{Material and methods}

A total of 24 specimens of $X$. atrata were collected in Ks: Kuusamo, Finland (10.-12.VII. 2001, Kronholm, Lundsten and Silvonen leg.). Three females laid eggs in plastic jars marked A1, $\mathrm{A} 2$ and A3. The larval description is based on a dozen larvae of A1 sent as ova to the senior author. The rearing took place in $24 \mathrm{~h}$ artificial daylight; the first specimen was full-grown September $1^{\text {st }}$. Five larvae were preserved in alcohol in the early instars and two in the last instar after they died during the winter. A few larvae hibernated successfully in a refrigerator and outdoors. Five full-grown larvae were preserved by blowing. The habitus of the living larvae was described and photographed. The hypopharyngeal complex, labrum and mandibles were prepared on a slide and drawn with a drawing tube. The distances between setae of blown larvae were measured with a Wild M3 microscope. The description of chaetotaxy is based on Hinton's (1946) nomenclature, except setae of the anal plate that follows Stehr (1987). The terms of ornamentation are according to Beck $(1974,1999)$. The species nomenclature follows Kullberg et al. (2002).

\section{Description of ovum, larva and pupa}

\subsection{Ovum}

Ova laid in small batches or sometimes singly (Fig. 1). Colour cream white when laid, later a darker ring develops around micropyle. Unfertilized eggs remain white. Ovum hemispherical, ribbed and reticulate, as typical for genus. First larvae hatched after 10 days in room temperature. Chorion not consumed.

\subsection{Larva}

Ornaments. Head brown with darker longitudinal stripes. Coronal stripe dark brown, narrow, frontal stripe absent or a dark brown fleck between setae AF2 and P1, supraocellar stripe dark brown, narrow, broken cephalad from seta L1, ocellar

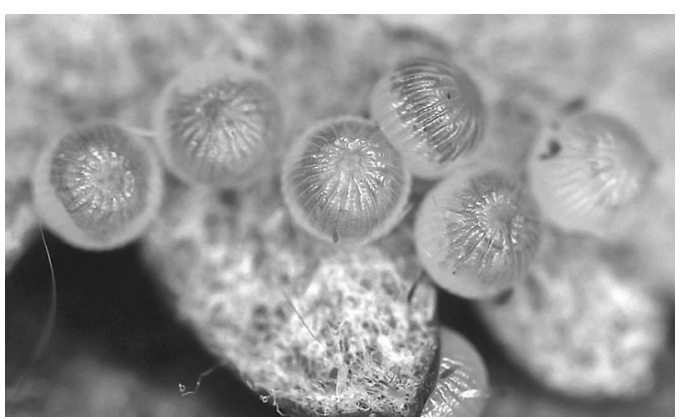

Fig. 1. Egg batch of $X$. atrata on Dryas octopetala.

stripe brown, weak. Setal points of head dark brown or black without colour spots at bases. Frons and anterior zone pale yellowish brown, adfrons darker brown. Ocellar zone above $1^{\text {st }}-4^{\text {th }}$ ocelli weak, pale yellowish brown, darker around setae $\mathrm{O} 1$ and $\mathrm{O} 2$ ventrad from ocelli. Dorsal groups 1-3 of reticular pattern between stripes well visible with pale yellowish brown fields and narrow, dark brown bands, but groups 4-5 on pale yellowish brown gena weak or absent (Fig. 2).

Thoracic plate. Pale greyish brown, paler than dorsal zone of larva. Middorsal and subdorsal stripes absent, setal points black without colour spots at bases. Four transverse rows of tonofibrillary platelets weak, greyish, lateral platelets forming a blackish line on ventral margin of thoracic plate.

Anal plate. Yellowish brown with weak, darker brown colour elements between setae D1. Setal points black, platelets dark brown without the surrounding paler flecks.

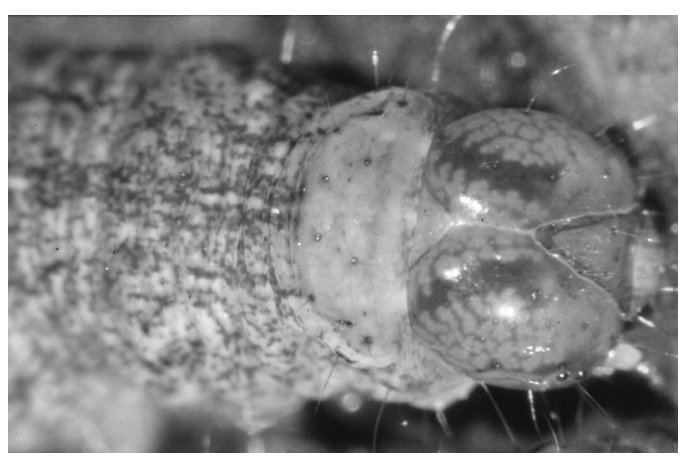

Fig. 2. Head of larva of $X$. atrata in frontal view. 


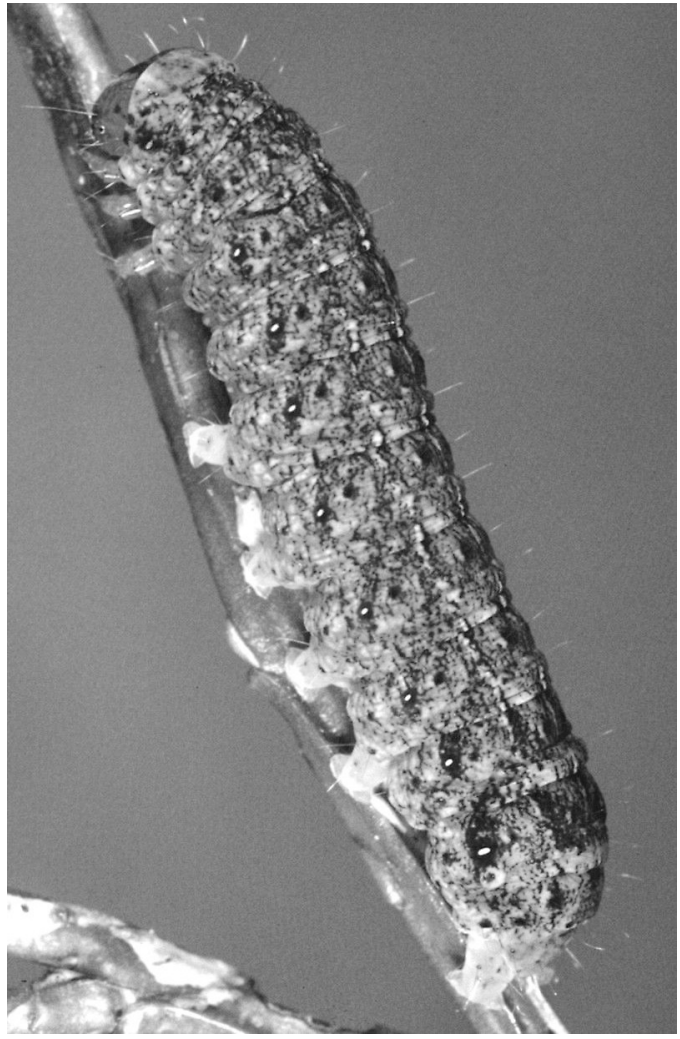

Fig. 3. Larva of $X$. atrata in dorsolateral view.

Abdomen. Brown with middorsal and subdorsal longitudinal lines, supraspiracular (= epistigmatal) and spiracular (= lateral) lines very weak or absent. Lines yellowish white, narrow, broken to spots, often visible only on posterior part of segments. Margin of middorsal line blackish, narrow, forming intersegmental fleck between abdominal segments $1-8$, subdorsal line bordered with a narrow dark brown margin on both sides. Dorsal zone greyish brown with a segmental series of pale greyish area caudad from D2 seta to posterior margin of segment. Darker brown colour elements forming weak diamondshaped pattern on dorsum, this fleck broken on 8th abdominal segment by a pale greyish-brown transverse stripe caudad from D2 setae. Setal points black with small, bicoloured spots at bases, those of D2 setae touching subdorsal line, black dorsal part of D1 bases well visible. Subdorsal zone pale yellowish brown with dark brown colour elements. Setal points black, base of SD1 bicoloured, black dorsal part larger than white ventral one. Spiracles greyish with black rims surrounded by a dark brown fleck. Pleural zone greyish brown with rather large white colour elements closer together in position of spiracular line. The border between subdorsal and pleural zones obscure. Ventral zone grey mottled by white colour elements, setae arising from small pale spot other than setal rim. Abdominal prolegs pale greyish with reddish tinge. Thoracic legs greyish, sclerotized part pale yellowish brown (Fig. 3).

Chaetotaxy. Seta SD1 hair-like on thorax and $9^{\text {th }}$ abdominal segment, SV group bisetose in the 1 st and trisetose in the 2nd abdominal segment, seta D2 2-3 times as long as the height of spiracle of the $8^{\text {th }}$ abdominal segment, setae SD1 and SD2 on $2^{\text {nd }}$ and $3^{\text {rd }}$ thoracic segment connected to muscle attachment by dark sclerotized bar. Ratios of setal distances are shown in Table 1.

Mouthparts. Spinneret flattened, about 2.5 times as long as broad, with shortly fringed dorsal lip and finely grooved dorsal skin, ventral lip straight, smooth. Length of Lps1 of labial palpus

Table 1. Ratios of setal distances between larvae of $X$. atrata and $X$. speciosa group. Abbreviations: Oc1-6 = ocelli, S1-10 = abdominal segments 1-10, ST1-8 = spiracles 1-8.

\begin{tabular}{lll}
\hline Ratio of setae & $\begin{array}{l}\text { X. atrata } \\
\text { Min-Max (Mean, Stdv) N }\end{array}$ & $\begin{array}{l}\text { X. speciosa group } \\
\text { Min-Max (Mean, Stdv) N }\end{array}$ \\
\hline Head: A1-F1/A1-A2 & $1.5-1.7(1.62,0.06) 5$ & $1.7-2.4(2.03,0.03) 36$ \\
Head: P1-A2/A1-A2 & $1.6-1.9(1.75,0,11) 5$ & $1.9-3.2(2.37,0.06) 36$ \\
Head: Oc1-Oc2/Oc2-Oc3 & $1.0-1.4(1.23,0.16) 5$ & $0.5-1.0(0.79,0.03) 36$ \\
S2: SD1-SD2/SD2-ST2 & $2.1-3.3(2.73,0.57) 5$ & $1.1-2.4(1.88,0.43) 43$ \\
S8: SD1-SD2/SD2-ST8 & $2.7-4.5(3.67,0.79) 5$ & $1.6-3.2(2.35,0.06) 44$ \\
S9: D2-SD1/D1-D2 & $1.3-1.4(1.38,0.04) 5$ & $1.4-2.5(1.64,0.13) 42$
\end{tabular}



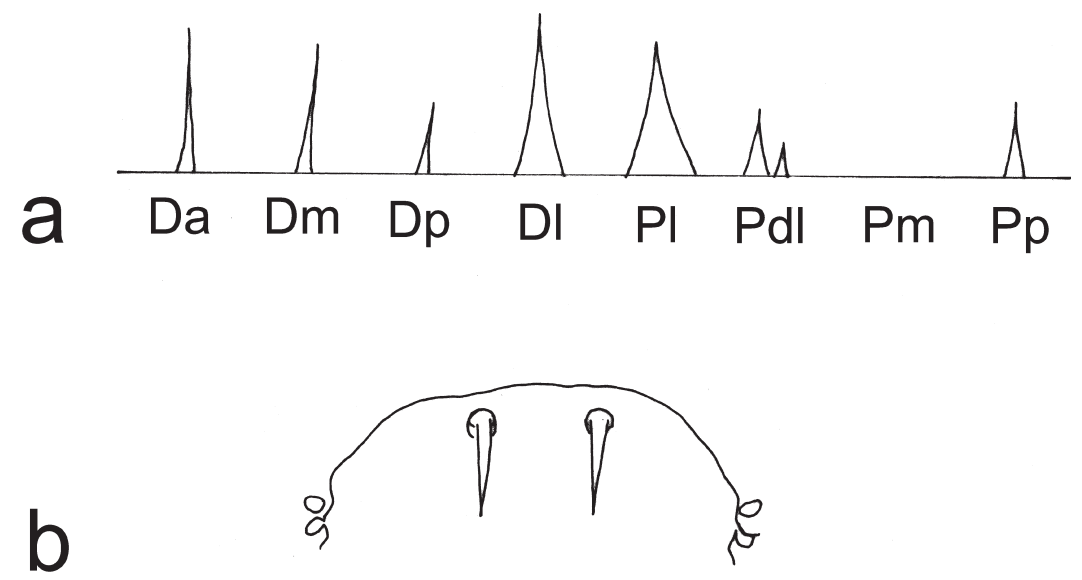

Fig. 4. X. atrata, spinneret, stipular setae and spines of hypopharynx. -a. Scheme of hypopharyngeal spines. $-b$.

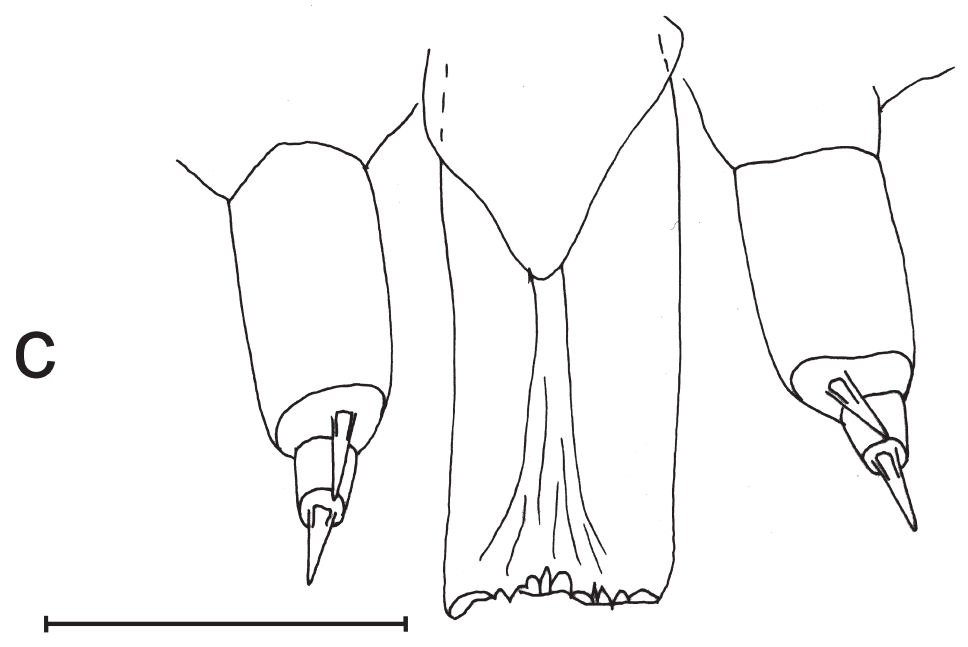
Stipular setae in dorsal view. - c. Spinneret and labial palpi in dorsal view. Abbreviations of hypopharynx: $\mathrm{Da}=$ anterior distal spines, Dm $=$ medial distal spines, $\mathrm{Dp}=$ posterior distal spines, $\mathrm{DI}=$ lateral distal spines, $\mathrm{Pl}=$ proximolateral teeth, $\mathrm{Pdl}=$ proximolateral spines dorsad from lateral teeth, $\mathrm{Pm}=$ medial spines of posterior region, $\mathrm{Pp}=$ posterior spines of proximolateral part. Scale 0.1 $\mathrm{mm}$.

short ( $<2$ times as long as broad), Lps2 shorter than Lp1, seta Lp1 as long as Lp2, shorter than stipular seta (Fig. 4). Hypopharynx is spiny except proximomedial part, distal region with long and narrow spines above spinneret, group of spines of distal lateral part long and broad. The stout lateral teeth of hypopharynx (8-12 in total) forming a row. Spines above teeth rather short (Figs. 4-5). Galeal lobe of maxillae present with two sensilla styloconica of equal size, stipital lobe finely spinulated (Fig. 6). Labrum rounded with a low notch and lateral setae close together (Fig. 7). Cutting margin of mandible with normal six teeth, two inner teeth present in $1^{\text {st }}$ and $2^{\text {nd }}$ inner ridges, three ridges terminating in process before cutting margin (Fig. 8).

\subsection{Pupa}

Colour of pupa of $X$. atrata (Fig. 9) similar to that of Xestia speciosa (Hübner, [1813]). With measurements of approximately $15 \mathrm{~mm}$ x $5 \mathrm{~mm}$, former clearly shorter. Labium, labial palps and fore tibia visible. Abdominal segments 4 to 7 dorsally finely punctured. Middle legs hardly longer than antennae or proboscis. Limit of metanotum rounded. Spiracles of abdomen narrow, seta L2 caudad from it. Cremaster short, dorsally and ventrally wrinkled, with a pair of hook-formed stronger D2, setaceous L1 located close to D2 and a pair of weak SD1 setae, seta D1 absent. 


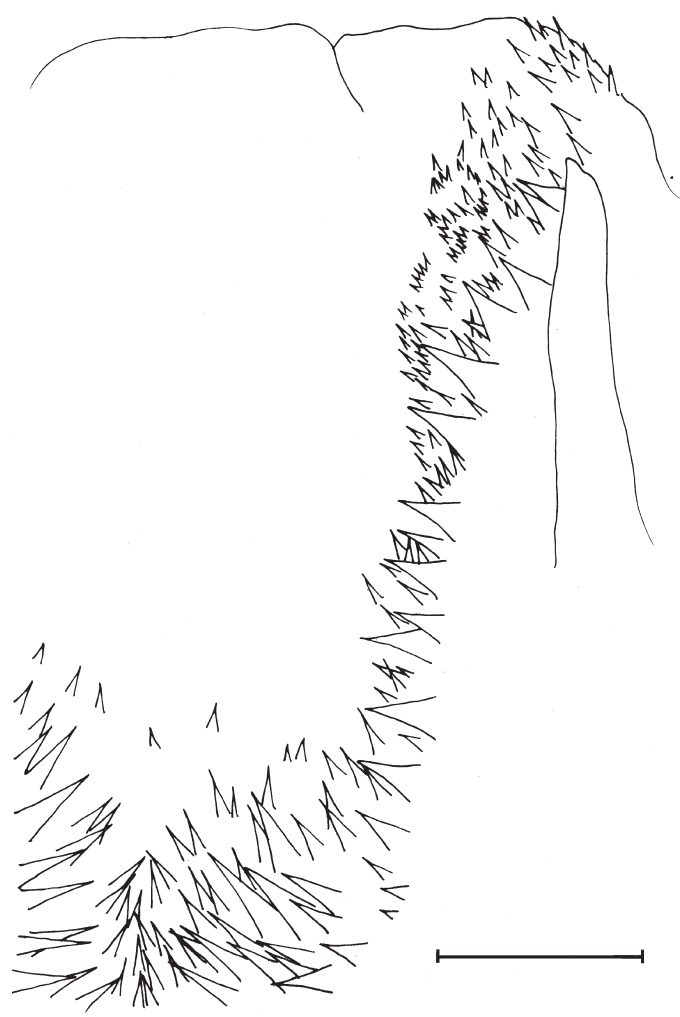

Fig. 5. X. atrata, hypopharynx in dorsal view. Scale 0.1 $\mathrm{mm}$.

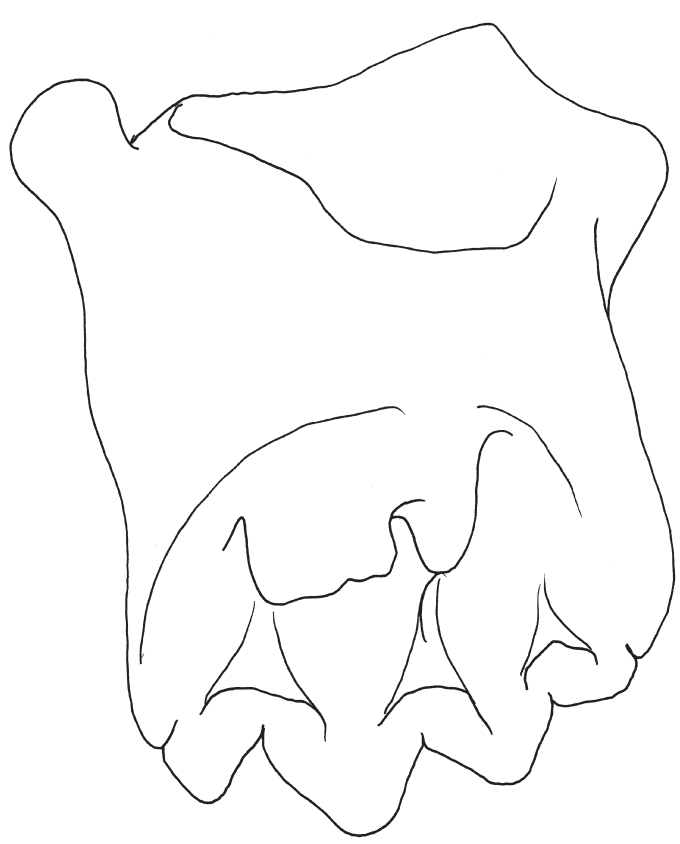

Fig. 8. $X$. atrata, inner surface of left mandible. Scale $0.1 \mathrm{~mm}$.

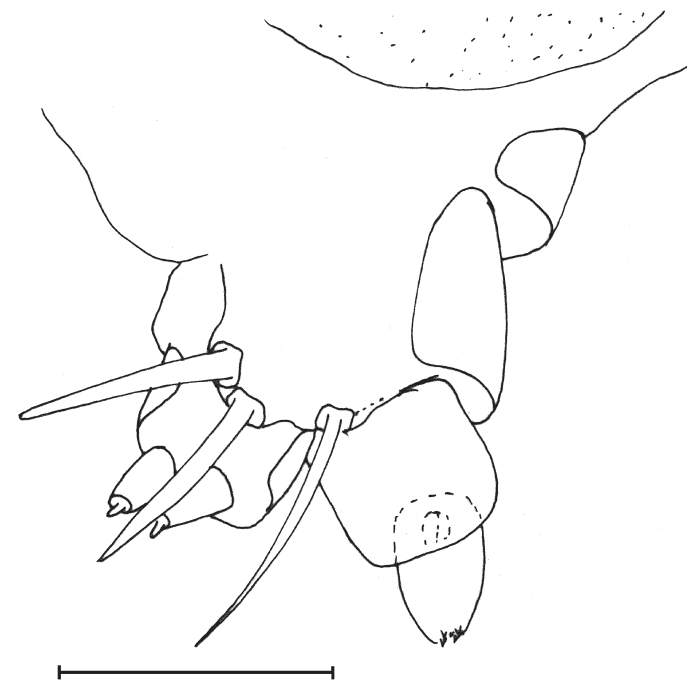

Fig. 6. $X$. atrata, left maxillae and laciniogalea in dorsal view. Scale $0.1 \mathrm{~mm}$.

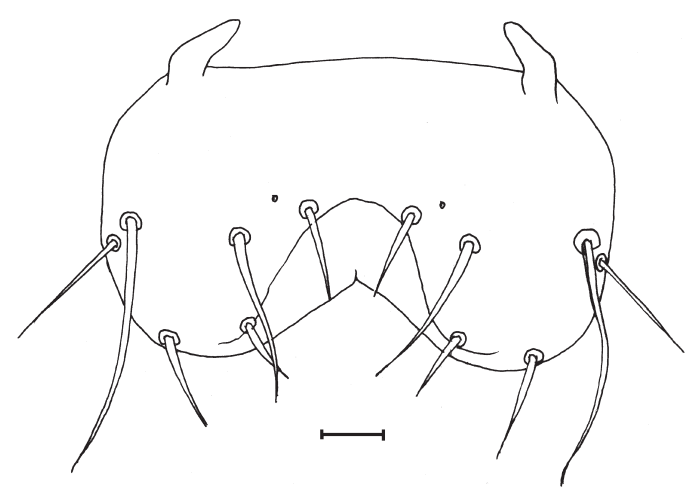

Fig. 7. X. atrata, labrum in frontal view. Scale $0.1 \mathrm{~mm}$.

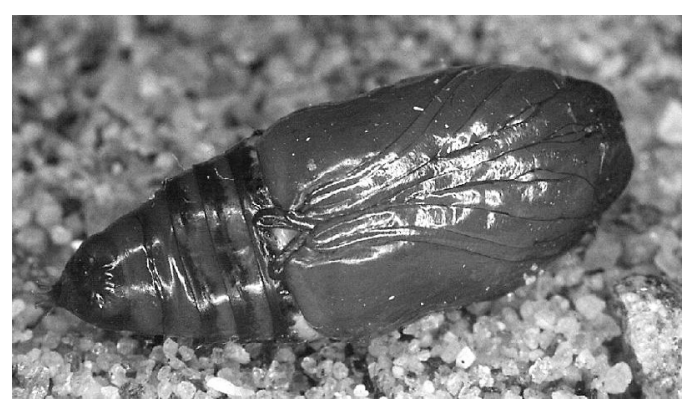

Fig. 9. Pupa of $X$. atrata. 


\section{Habitat and biology}

The habitat of $X$. atrata in Oulanka is a half-open seep surface spruce forest with a lush vegetation due to the calcareous ground. Many limestoneconfined plants, like Dryas octopetala, Actea erythrocarpa, Arnica angustifolia, Saxifraga cespitosa, S. aizoides and Salix reticulata, occur in the area (Jäkäläniemi 1993).

The place is a ravine, situated about $50-80 \mathrm{~m}$ below the surrounding forest area. Stone surface is widely open because of the steep walls of the ravine. South-exposed slopes are effectively absorbing the heat of the sun by day and radiate it back at night. Piles of bigger and smaller stone blocks are formed by surface disintegration caused by erosion on the bottom of the ravine. The cool north-exposed slopes and the bottom of the valley are under snow cover till late spring (Sundell 2003).

One of the first two females (A1) captured on 10.7. started egg-laying during the night between 11.-12.VII. Of the dozen eggs, 10 were laid on a single batch underneath a Dryas leaf, two others on the beard moss. Other plants available were Salix reticulata, Polygonum viviparum, Saxifraga aizoides and Vaccinium myrtillus. Dryas was added to both jars in the next day.

The other female (A2) started also laying between the $12^{\text {th }}$ and $13^{\text {th }}$ of July. The two females laid in total 110 and 90 eggs, respectively. The specimen of 11.VII. (A3) was captured on the top of the wall, when it was flying on the ground level near a sugar bait. It laid only five unfertilized eggs.

Some $70 \%$ of the eggs were laid on Dryas octopetala. The small jar (diameter $4.5 \mathrm{~cm}$, height $7.5 \mathrm{~cm}$ ) may not give a right picture about egglaying in more natural circumstances. Newly hatched larvae were observed sitting on dry leaves of Dryas and Saxifraga. Several other plants were accepted as well: Saxifraga hybr. arendsii, Filipendula ulmaria, Rubus idaeus, Polygonum aviculare, P. alpina, Vaccinium myrtillus, V. uliginosum, V. vitis-idaea (not well), and Empetrum nigrum (not well). They did not feed on Taraxacum sp., Rumex acetosella, Plantago major, Picea abies, Pinus sylvestris, Alnus incana, Populus tremula or Betula pubescens. Last two instar larvae fed also on Larix sibirica. The larva hibernates probably twice. In rearing conditions, the larvae pupated after the hibernation without feeding anything after late autumn.

\section{Discussion}

The larvae resemble those of $X$. speciosa, (Hübner, [1813]) and X. mixta (Walker, 1856) a lot (Lafontaine 1998). Setae SD1 and SD2 are connected to muscle attachment on $2^{\text {nd }}$ and $3^{\text {rd }}$ thoracic segment of atrata and the body colour is brown. Thoracic shield is paler than body as in $X$. mixta. The following differences are found:

- Dark brown flecks are present around spiracles of atrata. There is a violet tinge in the dorsal margin of spiracular line, but dark flecks are lacking in speciosa and mixta.

- The ventral zone of atrata is nearly of the same colour as the dorsum as opposed to the contrasting light ventral part of speciosa and mixta. Base spots of V and SV groups of setae are, however, pale.

- The ground colour of atrata is more reddish brown.

- Seta Lp2 of labial palpi are as long as seta Lp1, but shorter than stipital seta.

- Position of seta A2 of head is located closer to seta $\mathrm{P} 1$, ratio of distances $\mathrm{P} 1-\mathrm{A} 2 / \mathrm{A} 1-\mathrm{A} 2$ ranges $1.6-1.9$ (mean $1.75, \mathrm{~N}=5$ ). In the speciosa group this ratio varies 1.9-3.2 (mean $2.37, \mathrm{~N}=36$ ).

- Setal distance D1-D2 of the 9th abdominal segment is rather long, the ratio of distances D2-SD1/D1-D2 varies between 1.3-1.4 (mean 1.38, $\mathrm{N}=5$ ). The same ratio varies in the speciosa group from 1.4 to 2.5 (mean $1.64, \mathrm{~N}=42$ ).

- Ocellar distance Oc1-Oc2 > Oc2-Oc3, ratio of them between 1.0-1.4 (mean 1.23, $\mathrm{N}=5$ ). Larvae of the speciosa group have longer distance between Oc2 and Oc3, Oc1-Oc2< Oc2-Ox3 (ratio 0.5-1.0, mean 0.79, $\mathrm{N}=36$ ).

According to Lafontaine (1998), the larva of $X$. ursae (McDunnough, 1940) is close to that of $X$. atrata. Larvae of the both species have ventral setae arising from a pale spot, setae SD1 and SD2, however, they are not connected to muscle attach- 
Table 2. The flight season of Xestia atrata in relation to the other Xestia species in Oulanka in 2001.

\begin{tabular}{lcccrrr}
\hline & 7.-17.6. & 18.-26.6. & 27.6.-8.7. & 9.-15.7. & 16.-25.7. & 26.7.-12.8. \\
\hline Xestia gelida & 0 & 2 & 40 & 0 & 2 & 0 \\
Xestia sincera & 0 & 5 & 51 & 1 & 0 & 0 \\
Xestia atrata & 0 & 1 & 1 & 9 & 3 & 0 \\
Xestia speciosa & 0 & 0 & 2 & 355 & 4,860 & 1,293 \\
Xestia distensa & 0 & 0 & 0 & 2 & 39 & 5 \\
Xestia alpicola & 0 & 0 & 0 & 3 & 97 & 22 \\
Xestia fennica & 0 & 0 & 0 & 10 & 897 & 653 \\
\hline
\end{tabular}

ment on $2^{\text {nd }}$ and $3^{\text {rd }}$ thoracic segment of $X$. ursae. Following the key of Beck (1999), the ornamentation of $X$. atrata larva resembles that of $X$. speciosa, too. The larvae of different populations of $X$. lorezi vary much as pointed out by Ahola \& Lafontaine (1990). The possible variation between larval stages of $X$. atrata subspecies remains unknown to us.

Xestia species (subgenus Pachnobia) are known to usually feed on Vaccinium (Brandt 1937, Brown \& McGuffin 1942, Imby \& Palmqvist 1978, Seppänen 1970, Ahola \& Silvonen 1981, Lafontaine 1998) and other herbs, while Dryas is known as a foodplant only for high arctic species, e.g. X. lyngei (Rebel, 1923) (J. Silvonen, pers. comm.). According to Hydén \& Sjökvist (1993), young $X$. sincera (Herrich-Schäffer, 1851) larvae feed on Vaccinium myrtillus and after the second hibernation on Picea excelsa (see also Valkeila 1963, Skvortsov \& Thompson 1973). X. borealis (Nordström, 1933) may have the same strategy (Várkonyi \& Ahola 2001). The authors visited the habitat of $X$. atrata on 24.VI. 2000 trying to beat or sweep larvae, but without success. Only larvae of Xestia speciosa, X. sincera and X. tecta (Hübner, [1808]) were found. No larvae were searched for on the steep wall. The Dryas and Saxifraga carpets on the bottom of the ravine were neither investigated. The host plant preferences of the larva, if differing clearly from the other species of the genus, are possibly related to its habitat selection. The natural food plant of $X$. atrata remains unknown until more research in the field is done.

The Xestia species caught by bait traps in the Oulanka Lepidoptera survey can be divided into two phenological groups. Xestia sincera, X. geli$d a$ (Sparre-Schneider, 1883) and $X$. atrata begin their flight in the early season. X. brunneopicta (Matsumura, 1925) might also be considered belonging to this group, based on the few records in Oulanka area. Xestia speciosa, X. distensa, X. alpicola (Zetterstedt, 1839) and X. fennica (Brandt, 1936) do not start their flight until the other group's flight period is almost over (Table 2). The three $X$. atrata specimens in 1999 were caught between 21.VI. and 25.XII. No specimens were found in 2000 despite of the extensive bait-trapping. In 2001, additional 14 specimens were captured by bait trapping between 18.VI.-25.VII.

Acknowledgements. We are grateful to Lauri Kaila for valuable discussion and comments on the manuscript. Thanks are also due to two anonymous referees for their constructive criticism.

\section{References}

Ahola, M. \& Lafontaine, J. D. 1990: Larvae of Xestia kolymae (Herz) and Xestia lorezi (Staudinger)) (Lepidoptera: Noctuidae), with notes on the geographical variation of the latter. — Ent. Scand. 21: 77-90.

Ahola, M. \& Silvonen, J. 1981: The immature stages of Xestia kongsvoldensis and X. tecta (Lepidoptera: Noctuidae). - Notulae Ent. 61: 183-189.

Beck, H. 1974: Zur Beschreibung der Zeichnung (Ornamentik) von Insektenlarven. Eine Anleitung am Beispiel von Noktuidenlarven. - Atalanta 5: 121-143.

Beck, H. 1999: Die Larven der Europäischen Noctuidae. - Herbipoliana, Vol. I.

Brandt, W. 1937: Beitrag zur Kenntnis der Gattung Anomogyna Stgr. — Entomol. Rdsch. 55: 93-97.

Brown, A. W. A \& McGuffin, W. C. 1942: New descriptions of larvae of forest insects; II, Anomogyna (Lepidoptera, Phalaenidae). - Can. Entomol. 74: 21-25.

Fibiger, M. 1997: Noctuidae Europaeae. Vol III, Noctuinae III. - Sorø.

Hinton, H. E. 1946: On the homology and nomenclature of the setae of lepidopterous larvae, with some notes on 
the phylogeny of the Lepidoptera. - Trans. R. Ent. Soc. Lond. 97: 1-37.

Hydén, N. \& Sjökvist, P. 1993: Barrskogsfjällflyet, Xestia sincera (Lepidoptera, Noctuidae), och det moderna storskaliga skogsbruket [Xestia sincera (Lepidoptera, Noctuidae) and the modern large scale forestry]. Entomol. Tidskr. 114(1-2): 1-11.

Imby, L. \& Palmquist, G. 1978: De svenska Anomogynaarternas utseende, biologi och utbredning (Lep. Noctuidae). — Entomol. Tidskr. 99: 97-107.

Jäkäläniemi, A. 1993: Threatened vascular plants of some rocks in the Oulanka National park, northeastern Finland. - Oulanka Reports 12: 29-44.

Kullberg, J., Albrecht, A., Kaila, L., \& Varis, V. 2002: Checklist of Finnish Lepidoptera - Suomen perhosten luettelo. - Sahlbergia Vol. 6: 45-190.

Lafontaine, J. D. 1998: Noctuoidea, Noctuidae (part). In Dominick, R. B. \& al. (eds.), The Moths of America North of Mexico, fasc. 27.3.

Lafontaine, J. D., Mikkola, K. \& Kononenko, V. S. 1987: A revision of the genus Xestia subg. Pachnobia (Lepidoptera: Noctuidae), with descriptions of four new species and subspecies. - Entomol. Scand. 18: 305331.

Nupponen, K. \& Fibiger, M. 2002: Contribution to the knowledge of the fauna of Bombyces, Sphinges and Noctuidae of the Southern Ural Mountains, with de- scription of a new Dichagyris (Lepidoptera: Lasiocampidae, Endromidae, Saturnidae, Sphingidae, Notodontidae, Noctuidae, Pantheidae, Lymantriidae, Nolidae, Arctiidae). — Phegea 30 (4): 121-185.

Ryrholm, N. 1995: Intressanta fynd av storfjärilar (Macrolepidoptera) I Sverige 1994. — Entomol. Tidskr. 116: 31-45.

Seppänen, E. J. 1970. Suurperhostoukkien ravintokasvit. Suomen eläimet 14. - Porvoo, 179 pp.

Skvortsov, V. \& Thomson, E. 1973: Der Vorkommen und Ekologie von Amathes sincera (Lep.Noctuidae) in Estland. — Entomol. Z. 83(10): 117-120.

Stehr, F. W. 1987: Immature insects. — Dubuque, XIV + $754 \mathrm{pp}$.

Sundell, P. R. \& Lundsten K.-E., 2000: Xestia atrata Suomelle vanha yökköslaji (Xestia atrata - an old noctuid species to Finland). - Baptria 25: 92-95.

Sundell, P. R. 2003: Tummaharmoyökköselvitys (Xestia atrata) Oulangan kansallispuistossa 2003 (An Inventory of Xestia atrata in Oulanka National Park 2003). - Raportti Perhostensuojelutoimikunnalle.

Valkeila, E. 1963: Zur Kenntnis der Raupe von Anomogyna sincera H.S. (Lep., Noctuidae) und ihrer Lebensweise. - Ann. Entomol. Fenn. 29: 249-252.

Várkonyi, G. \& Ahola, M. 2001: Notes on the larval biology of Xestia borealis (Lepidoptera: Noctuidae). Entomol. Fennica 12: 78-80. 